\title{
UPAYA MENINGKATKAN KEMAMPUAN PEMECAHAN MASALAH MATEMATIKA SISWA DENGAN MENGGUNAKAN MODEL PEMBELAJARAN PROBLEM BASED LEARNING DI KELAS X SMA
}

\author{
Marojahan Panjaitan, Sri R Rajagukguk \\ Prodi Pendidikan Matematika , Fakultas Matematika dan Ilmu Pengetahuan Alam, \\ Universitas Negeri Medan (UNIMED), 2201 Medan, Sumatera Utara, Indonesia \\ E-mail : marojahanpjtn@yahoo.com \\ E-mail: srirez216@gmail.com
}

\begin{abstract}
ABSTRAK
Penelitian ini bertujuan untuk mengetahui bagaimana peningkatan kemampuan siswa dalam memecahkan masalah matematika pada materi persamaan Linear dua variabel di kelas X SMA Negeri 14 Medan setelah diterapkan model pembelajaran Problem Based Learning. Penelitian ini adalah penelitian tindakan kelas yang dilaksanakan dalam 2 siklus yang masing-masing siklus dilaksanakan dalam 3 kali pertemuan. Subjek dalam penelitian ini adalah siswa kelas $X$ yang berjumlah 35 orang. Objek dalam penelitian ini adalah upaya meningkatkan kemampuan pemecahan masalah matematika pada materi persamaan Linear dua variabel.Berdasarkan hasil tes diagnostik diketahui tingkat kemampuan pemecahan masalah matematika siswa tergolong rendah dimana jumlah siswa yang telah mencapai ketuntasan sebanyak 4 siswa dari 35 siswa atau 11,43\%, sedangkan jumlah siswa yang belum mencapai ketuntasan sebanyak 31 siswa dari 35 siswa atau 88,57\% dengan nilai rata-rata kelas 20,06. Setelah pemberian tindakan pada siklus I, diperoleh sebanyak 24 siswa dari 35 siswa atau 68,57\%, telah mencapai ketuntasan kemampuan pemecahan masalah, sedangkan sebanyak 11 siswa dari 35 siswa atau 31,42\% belum tuntas dengan nilai rata-rata kelas 70,79 dapat dilihat bahwa tingkat kemampuan pemecahan masalah matematika siswa masih dalam kategori sedang dan kemampuan guru mengelola pembelajaran adalah 2,85 dengan kategori baik. Selanjutnya, setelah pelaksanaan tindakan pada siklus II, diperoleh jumlah siswa yang telah mencapai ketuntasan belajar sebanyak 33 siswa atau 94,29\% dari seluruh siswa dan 2 siswa dari 35 siswa atau 5,71\% belum tuntas dengan nilai rata-rata kelas 84,36 sehingga kemempuan pemecahan masalah siswa sudah dalam kategori baik. Kemampuan guru mengelola pembelajaran adalah 3,35 dengan kategori sangat baik. Dengan demikian dapat dikatakan kelas tersebut telah terdapat lebih dari $85 \%$ siswa yang telah tuntas memecahkan masalah. Sehingga dapat disimpulkan bahwa terjadi peningkatan kemampuan pemecahan masalah matematika siswa. Sehingga pembelajaran dengan menggunakan model pembelajaran Problem Based Learning ini dapat dijadikan salah satu alternatif pembelajaran.

Kata kunci : Kemampuan Pemecahan Masalah Matematika, model pembelajaran Problem Based Learning, Sistem Persamaan Linear dua variabe
\end{abstract}

Marojahan Panjaitan, Sri R Rajagukguk. Upaya Meningkatkan Kemampuan Pemecahan Masalah Matematika Siswa dengan Menggunakan Model Pembelajaran Problem Based Learning di Kelas X SMA. Jurnal Inspiratif, Vol. 3 No. 2 Agustus 2017 


\begin{abstract}
This study aims to find out how to improve the ability of students in solving mathematical problems on the matter of Linear equations of two variables in class X SMA Negeri 14 Medan after applied model of learning Problem Based Learning. This study is a classroom action research conducted in 2 cycles, each cycle is implemented in 3 meetings. Subjects in this study were students of class $X$ which amounted to 35 people. The object of this research is the effort to improve the problem solving ability of mathematics on the material of Linear equation of two variables. .Based on the diagnostic test results known level of problem solving ability of students mathematics classified low where the number of students who have reached mastery as many as 4 students from 35 students or $11.43 \%$, while the number of students who have not reached completeness as many as 31 students from 35 students or $88.57 \%$ with grade average grade 20.06. After giving the action in cycle I, obtained as many as 24 students from 35 students or $68,57 \%$, have reached the completeness of problem solving ability, while as many as 11 students from 35 students or 31,42\% not yet complete with grade average grade 70,79 it can be seen that the level of problem solving ability of student math is still in the medium category and the ability of teachers to manage learning is 2.85 with good category. Furthermore, after the implementation of the action in cycle II, obtained the number of students who have achieved mastery of learning as much as 33 students or $94.29 \%$ of all students and 2 students of 35 students or $5.71 \%$ not complete with the average grade grade 84.36 so that the problem solving of students is in good category. The ability of teachers to manage learning is 3.35 with very good category. Thus it can be said that the class has been there more than $85 \%$ of students who have completed solve the problem. So it can be concluded that there is an increase in problem solving skills of mathematics students. So that the learning by using the model of learning Problem Based Learning can be used as an alternative learning.

Keywords: Mathematical Problem Solving Abilities, Problem Based Learning, Linear Equation in two variable System.
\end{abstract}

\section{Pendahuluan}

Pendidikan merupakan usaha sadar untuk menumbuhkembangkan potensi yang ada dalam diri manusia melalui kegiatan pengajaran. Pendidikan adalah perbuatan atau proses untuk memperoleh pengetahuan. Pembelajaran merupakan proses komunikasi dua arah, mengajar yang dilakukan oleh guru, dan belajar yang dilakukan oleh siswa. Dalam hal ini, peranan guru bukan semata-mata memberikan informasi, melainkan juga mengarahkan dan memberi fasilitas belajar agar proses belajar lebih memadai.

Matematika sebagai salah satu pengetahuan mendasar dinilai memegang peranan yang sangat penting dalam membentuk siswa yang berkualitas, dan cerdas. Karena matematika merupakan suatu sarana berpikir untuk mengkaji sesuatu secara logis dan sistematis dalam perkembangan teknologi saat ini, dimana tujuan pembelajaran matematika dalam BSNP (dalam Wicaksana, 2014) :

1. Melatih cara berpikir dalam bernalar atau menarik kesimpulan, misalnya melalui kegiatan penyelidikan, eksplorasi, eksperimen, menunjukkan kesamaan, perbedaan, konsistens, dan inkonsistens.

2. Mengembangkan aktifitas yang menyebabkan imajinasi, intuisi, dan penemuan, mengembangkan

Marojahan Panjaitan, Sri R Rajagukguk. Upaya Meningkatkan Kemampuan Pemecahan Masalah Matematika Siswa dengan Menggunakan Model Pembelajaran Problem Based Learning di Kelas X SMA. Jurnal Inspiratif, Vol. 3 No. 2 Agustus 2017 
pemikiran divergen orisinal, rasa ingin tahu, membuat prediksi, dan dugaan sementara serta mencobacoba.

3. Mengembangkan kemampuan memecahkan masalah.

4. Mengembangkan kemampuan menyampaikan informasi atau mengkomunikasikan gagasan antara lain melalui pembicaraan lisan, catatan, grafik, peta, diagram dalam menjelaskan.

Hasratuddin (2015:30) juga mengungkapkan bahwa:

Matematika merupakan suatu sarana atau cara menemukan jawaban terhadap masalah yang dihadapi manusia, Sejalan dengan pendapat di atas, belajar matematika diharapkan dapat meningkatkan kemampuan berpikir, bernalar, mengkomunikasikan gagasan serta dapat meningkatkan aktifitas kreatif dan pemecahan masalah.

$$
\text { Ini menunjukkan bahwa }
$$
matematika memiliki manfaat dalam mengembangkan kemampuan siswa sehingga perlu untuk dipelajari. Cornelius (Abdurahman, M. 2009:253) mengemukakan bahwa

Lima alasan perlunya belajar matematika karena matematika merupakan (1) sarana berpikir yang jelas dan logis, (2) memecahkan masalah dalam kehidupan sehari-hari, (3) mengenal pola- pola hubungan dan generalisasi pengalaman, mengembangkan kreativitas, dan (5) meningkatkan kesadaran terhadap perkembangan budaya.

Hasil studi Programme for International Student Assessment (PISA) 2009 (dalam Wardhani \& Rumiati, 2011) menunjukkan sistem pendidikan indonesia yang masih sangat rendah.
Indonesia hanya menduduki peringkat 61 dari 65 negara dengan rata- rata skor 371, sementara rata- rata skor internasional adalah 496. Sedangkan pada Hasil studi Programme for International Student Assessment (PISA) 2012 menunjukkan sistem pendidikan Indonesia masih sangat rendah. Dari 65 negara anggota PISA, pendidikan Indonesia berada di bawah peringkat 64 . Untuk literasi matematika, pelajar Indonesia berada di peringkat 64 dengan skor 375. Adapun skor literasi sains berada di peringkat 64 dengan skor 382 . Berdasarkan hasil studi PISA 2009 dan 2012 dapat dilihat bahwa Indonesia mengalami kemerosotan dalam pendidikan, terbukti pada tahun 2009 indonesia berada pada peringkat ke 61 dan pada tahun 2012 Indonesia memperoleh peringkat ke 64 dari 65 negara. Selain itu, Berdasarkan laporan dari TIMSS (Trends in International Mathematic And Science Study) yang diikuti siswa kelas VIII Indonesia tahun 2011 untuk bidang matematika, Indonesia berada diurutan ke - 38 dari 42 negara yang siswanya di tes dengan skor 386, sedangkan skor rata-rata internasional 500. Oleh karena itu, kualitas pendidikan matematika di Indonesia hendaknya ditingkatksan seiring dengan perkembangan zaman.

$$
\text { Pada umumnya disekolah- }
$$
sekolah sering dijumpai siswa- siswi yang tidak tertarik belajar matematika. Hal ini terjadi karena pada kenyataannya dalam pelaksanaan pembelajaran matematika, metode pembelajaran yang diterapkan masih konvensional, yaitu berpusat pada guru. Sebagaimana dinyatakan oleh Trianto (2010:1) bahwa: "Berdasarkan hasil penelitian terhadap rendahnya hasil belajar peserta didik, hal tersebut disebabkan oleh pembelajaran yang didominasi oleh pembelajaran

Marojahan Panjaitan, Sri R Rajagukguk. Upaya Meningkatkan Kemampuan Pemecahan Masalah Matematika Siswa dengan Menggunakan Model Pembelajaran Problem Based Learning di Kelas X SMA. Jurnal Inspiratif, Vol. 3 No. 2 Agustus 2017 
tradisional. Pada pembelajaran ini suasana kelas cenderung teacher-centred sehingga siswa menjadi pasif". Selain itu, metode pembelajaran yang dilakukan guru kurang menciptakan komunikasi dan interaksi yang baik antara guru dengan siswa dan juga antara siswa dengan siswa yang menyebabkan proses belajar mengajar yang monoton. Siswa juga kurang berinteraksi dengan lingkungannya dalam proses pembelajaran.

Hal ini sesuai dengan yang diungkapkan oleh Isjoni (2009:40) menyatakan bahwa: "Interaksi antara guru dengan siswa dan interaksi antar siswa dalam kelas sangat berpengaruh besar terhadap hasil belajar. Interaksi yang saling mempengaruhi antar warga dikelas, melahirkan apa yang biasa dinamakan iklim atau suasana kelas".

Nurdalilah, dkk (2013) pada penelitiannya menyatakan bahwa banyak siswa yang mengalami kesulitan untuk memahami soal, menemukan dari apa yang diketahui dari soal, rencana penyelesaian tidak terarah dan proses perhitungan atau strategi penyelesaian dari jawaban yang dibuat siswa tidak benar.

Rendahnya kemampuan pemecahan matematika siswa juga diungkapkan oleh Napitupulu dan Mansyur (2011) dalam penelitiannya, yaitu kinerja siswa dalam pemecahan masalah masih dibawah 50\%. Hal ini sangat lemah dan jauh untuk dapat dikatakan tuntas.

Sama halnya dengan yang dikemukakan oleh Minarni (2013) Sebagian besar siswa tidak mampu membuat gambar, tabel dan atau diagram untuk membantunya menyelesaiakan masalah (soal). Kemampuan ini merupakan aspek menafsirkan (interprenting) dalam proses pemahaman matematis.

Sesuai yang dikemukakan oleh Mullis, dkk (dalam Minarni,2012) bahwa hasil pencapaian belajar matematika siswa SMP di Indonesia, rata-rata internasional dalam kemampuan pemecahan masalah dibidang aljabar hanya $8 \%$. Ini menunjukkan betapa rendahnya siswa Indonesia dalam penguasaan kemampuan pemecahan masalah matematis siswa.

Hasil studi pendahuluan yang dilakukan peneliti kepada siswa kelas $\mathrm{X}$ SMA Negeri 14 Medan pada Mei 2017, diperoleh bahwa hasil belajar siswa masih tergolong rendah. Pada saat peneliti melakukan observasi pada proses pembelajaran dikelas guru menggunakan metode ceramah dan tanya jawab namun pada kenyataan dikelas siswa tidak berperan aktif dalam menjawab pertanyaan dari guru sehingga mengakibatkan pengajaran yang bersifat satu arah. Hasil studi pendahuluan yang dilakukan peneliti kepada siswa kelas X SMA Negeri 14 Medan pada Mei 2017, diperoleh bahwa hasil belajar siswa masih tergolong rendah. Pada saat peneliti melakukan observasi pada proses pembelajaran dikelas guru menggunakan metode ceramah dan tanya jawab namun pada kenyataan dikelas siswa tidak berperan aktif dalam menjawab pertanyaan dari guru sehingga mengakibatkan pengajaran yang bersifat satu arah. Metode mengajar konvensional yang digunakan guru memperkecil kemungkinan siswa utuk terlibat aktif dalam bertanya, menjawab pertanyaan, mengeluarkan pendapat, dan berdiskusi dengan teman lain. Adapun yang menjawab biasanya siswa menyelesaikan soal dengan cara

Marojahan Panjaitan, Sri R Rajagukguk. Upaya Meningkatkan Kemampuan Pemecahan Masalah Matematika Siswa dengan Menggunakan Model Pembelajaran Problem Based Learning di Kelas X SMA. Jurnal Inspiratif, Vol. 3 No. 2 Agustus 2017 
menirukan cara guru atau contoh soal yang ada. Selain itu masalah ini diperkuat dengan hasil wawancara dengan guru mata pelajaran matematika di kelas X SMA Negeri 14 Medan yang mengatakan bahwa siswa masih mengalami kesulitan dalam pelajaran Sistem persamaan linear dua variabel, terutama dalam memecahkan masalah dan menentukan langkah- langkah penyelesaian serta metode apa yang harusnya dilakukan untuk menyelesaikan setiap masalah tersebut.

Abdurrahman (2009: 257) mengemukakan bahwa: "Dalam menyelesaikan soal- soal cerita banyak anak yang mengalami kesulitan. Kesulitan tersebut tampak terkait dengan pengajaran yang menuntut anak membuat kalimat matematika tanpa terlebih dahulu memberikan petunjuk tentang langkah- langkah yang harus ditempuh". Kemampuan pemecahan masalah siswa yang rendah akan mengakibatkan hasil belajar siswa rendah pula. Siswa cenderung menghafalkan konsep- konsep matematika sehingga kemampuan siswa dalam memecahan masalah sangat kurang.

Hasil tes awal kepada 38 orang siswa kelas X MIPA 1 SMA N 14 Medan menunjukkan bahwa kemampuan pemecahan masalah siswa masih rendah. Pemberian tes awal menunjukkan bahwa siswa kurang mampu dalam menyelesaikan masalah yang diberikan. Dari 4 buah soal yang diberikan kepada 38 siswa, diperoleh deskripsi kemampuan siswa dalam memecahkan masalah, yaitu; Dari 38 siswa, hanya 4 siswa $(10,05 \%)$ yang memiliki kemampuan pemecahan masalah dengan kategori sedang karena sudah mampu memahami masalah dengan benar, mampu merepresentasikan masalah ke dalam bentuk konsep dasar yang benar, serta mampu menerapkan strategi dan memecahkan masalah walaupun masih salah dalam perhitungan. Sementara itu, terdapat 34 siswa $(89,47 \%)$ yang memiliki kemampuan pemecahan masalah dengan kategori rendah dikarenakan siswa belum mampu memahami masalah dengan benar.

Hudojo (2005) menyatakan bahwa :

Pemecahan masalah merupakan suatu hal yang sangat essensial didalam pengajaran matematika, disebabkan (1) siswa menjadi terampil menyeleksi informasi yang relevan, kemudian menganalisanya dan akhirnya meneliti hasilnya, (2) kepuasan intelektual akan timbul dari dalam, (3) potensi intelektual siswa meningkat.

Seorang siswa dikatakan memiliki kemampuan pemecahan masalah dalam pembelajaran matematika ketika siswa mencapai kriteria-kriteria tertentu atau biasa dikenal dengan indikator. Ada empat indikator pemecahan masalah matematika menurut Polya (1973:5), yaitu: 1) Understanding the problem (memahami masalah), yaitu mampu membuat apa (data) yang diketahui , apa yang tidak diketahui (ditanyakan), apakah informasi cukup, kondisi (syarat) apa yang harus dipenuhi, dan menyatakan kembali masalah asli dalam bentuk yang lebih operasional (dapat dipecahkan), 2) Devising a plan (merencanakan penyelesaian), yaitu dengan mencoba mencari atau mengingat masalah yang pernah diselesaikan yang memiliki kemiripan dengan masalah yang akan dipecahkan, mencari pola atau aturan, dan menyusun prosedur penyelesaian (membuat konjektur), 3) Carrying out the plan (melaksanakan rencana), yaitu

Marojahan Panjaitan, Sri R Rajagukguk. Upaya Meningkatkan Kemampuan Pemecahan Masalah Matematika Siswa dengan Menggunakan Model Pembelajaran Problem Based Learning di Kelas X SMA. Jurnal Inspiratif, Vol. 3 No. 2 Agustus 2017 
menjalankan prosedur yang telah dibuat untuk mendapatkan penyelesaian, dan 4) Looking back (melihat kembali), memeriksa bagaimana hasil itu diperoleh, memeriksa sanggahannya, mencari hasil itu dengan cara yang lain, melihat apakah hasilnya dapat dilihat dengan sekilas dan memeriksa apakah hasil atau cara itu dapat digunakan untuk soal-soal lainnya.

Dengan demikian, maka perlu adanya perbaikan dalam proses pembelajaran yang menerapkan masalah sebagai awal pembelajaran guna siswa dapat membangun pengetahuannya. Sebuah pembelajaran yang menantang dan memberikan kesempatan pada siswa untuk belajar mengkontruksi pengetahuannya. Arends (dalam Trianto, 2011: 25) menyeleksi enam model pengajaran yang sering dan praktis digunakan guru dalam mengajar, yaitu: presentasi, pengajaran langsung, pengajaran konsep, pembelajaran kooperatif, pembelajaran berdasarkan masalah, dan diskusi kelas. Arends dan pakar model pembelajaran yang lain berpendapat, bahwa tidak ada satu model pembelajaran yang paling baik di antara yang lainnya, karena masingmasing model pembelajaran dapat dirasakan baik, apabila telah diujicobakan untuk mengajarkan materi pelajaran tertentu.

$\begin{array}{rrr}\text { Salah } & \text { satu } & \text { model } \\ \text { permbelajaran } & \text { yang } & \text { dapat }\end{array}$
meningkatkan kemampuan pemecahan masalah adalah pembelajaran berbasis masalah atau yang dikenal dengan Problem Based Learning, dimana dalam pembelajaran ini guru memandu siswa menguraikan rencana pemecahan masalah menjadi tahap-tahap kegiatan; guru memberi contoh mengenai penggunaan keterampilan dan strategi yang dibutuhkan supaya tugas-tugas tersebut dapat diselesaikan. Guru menciptakan suasana kelas yang fleksibel dan berorientasi pada upaya penyelidikan siswa. (Trianto, 2011 : 23).

Padmavathy dan Maaresh (2013:47) mengemukakan bahwa: "PBL menggambarkan kegiatan belajar dimana dengan adanya masalah mendorong pembelajaran. Artinya, pembelajaran dimulai dengan masalah yang harus diselesaikan, dan masalah yang diajukan adalah sedemikian rupa sehingga siswa perlu mendapatkan pengetahuan baru sebelum mereka dapat memecahkan masalah". Sejalan dengan hal tersebut, Regehr dan Norman dalam (Mansor dkk. 2014:261) menyatakan bahwa: "PBL didasarkan pada asumsi bahwa belajar bukanlah Proses penerimaan, melainkan, konstruksi pengetahuan baru".

Penelitian ini mengangkat salah satu materi pokok matematika SMA yang sulit dipelajari oleh siswa. Salah satunya adalah Sistem Persamaan Linear Dua Variabel. Materi pokok ini dipilih dengan dasar pemikiran siswa sering menemukan kesulitan dalam pengoperasian bilangan bulat dan kurang teliti dalam menghitung. Siswa sering mengalami kesulitan dalam penggunaan atau penentuan simbol yang digunakan sebagai variabel dari soal yang akan dijawab dan bagaimana cara menyelesaikannya dan memecahkan masalahnya, siswa sering mengalami kesulitan dalam hal menghitung pecahan dalam bentuk aljabar, dan siswa sering mengalami kesulitan dalam menterjemahkan kalimat cerita menjadi kalimat matematika dalam bentuk persamaan, dan siswa kurang teliti dalam memeriksa kembali hasil yang telah diperoleh.

Dalam pembelajaran ini masalah-masalah yang dijadikan sebagai 
fokus dapat diselesaikan siswa melalui kerja kelompok sehingga dapat memberi pengalaman-pengalaman belajar yang beragam pada siswa sebagai kerjasama dan interaksi dlam kelompok, disamping pengalaman belajar yang berhubungan dengan pemecahan masalah seperti membuat hipotesis, merancanag percobaan, melakukan penyelidikan, mengumpulkan data menginterpretasikan data, membuat kesimpulan, mempresentasikan, berdiskusi dan membuat laporan.

\section{Metode Penelitian}

\section{Subjek dan Objek Penelitian}

Subjek dalam penelitian ini adalah siswa kelas X MIPA 1 SMA Negeri 14 Medan sebanyak 35 siswa. Pengambilan kelas X MIPA 1 sebagai subjek dilakukan berdasarkan dari hasil tes awal siswa Kelas X MIPA 1 menunjukkan kemampuan pemecahan masalah matematika di kelas tersebut masih rendah. Sehingga peneliti akan mengadakan penelitian di kelas tersebut.

Objek dalam penelitian ini adalah Penerapan Model Pembelajaran Problem Based Learning (PBL) untuk Meningkatkan Kemampuan Pemecahan Masalah matematika siswa.
PTK dilakukan melalui beberapa tahapan siklus yang akan dihentikan jika sudah memenuhi indikator keberhasilan. Siklus artinya putaran dan tiap siklus dilakukan melalui lima langkah yaitu perencanaan, tindakan, pengamatan, evaluasi dan refleksi. Pada penelitian ini jika siklus pertama tidak berhasil, yaitu proses belajar mengajar belum meningkatkan hasil belajar dan kemampuan komunikasi siswa yang terlihat dari tes kemampuan komunikasi matematika, maka akan diadakan siklus lanjutan sampai peningkatan hasil belajar dan kemampuan komunikasi matematika siswa tercapai. Penelitian tindakan kelas termasuk penelitian kualitatif meskipun data yang dikumpulkan dapat bersifat kuantitatif, dimana uraiannya bersifat deskriptif dalam bentuk kata-kata, peneliti merupakan instrumen utama dalam pengumpulan data, proses sama pentingnya dengan produk. Perhatian peneliti diarahkan kepada pemahaman bagaimana berlangsungnya suatu kejadian atau efek dari suatu tindakan. Adapun prosedur penelitiannya adalah sebagai berikut :

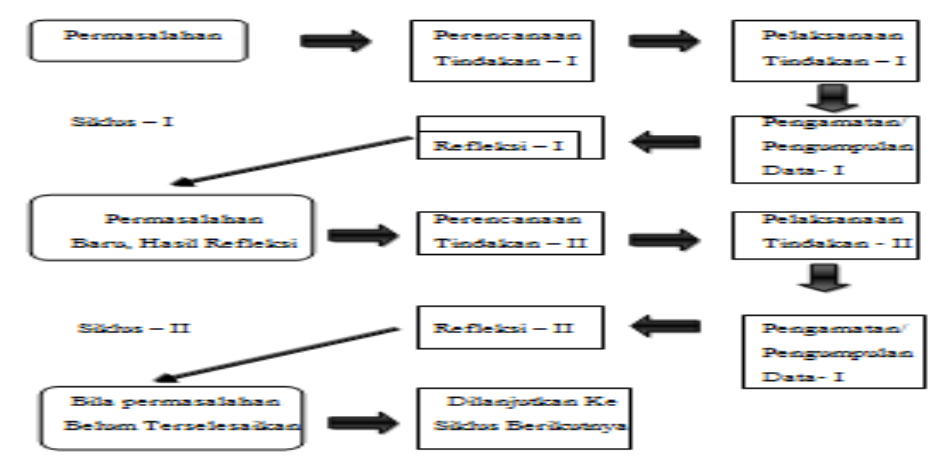

Gambar 1. Prosedur Penelitian

\section{Hasil Penelitian}

Berdasarkan hasil penelitian dapat disimpulkan bahwa kemampuan pemecahan masalah matematika siswa pada materi sistem persamaan linear dua variabel melalui penerapan Model

Marojahan Panjaitan, Sri R Rajagukguk. Upaya Meningkatkan Kemampuan Pemecahan Masalah Matematika Siswa dengan Menggunakan Model Pembelajaran Problem Based Learning di Kelas X SMA. Jurnal Inspiratif, Vol. 3 No. 2 Agustus 2017 
Pembelajaran Berbasis Masalah mengalami peningkatan. Hal ini dapat dilihat dari :

1. Peningkatan nilai rata-rata yang diperoleh siswa
Nilai rata-rata kelas pada tes kemampuan komunikasi siklus I 70,79 dan meningkat menjadi 84,36 pada siklus II. Lebih jelasnya dapat dilihat pada tabel berikut

Tabel 1. Deskripsi Kemampuan Siswa Setiap Siklus

\begin{tabular}{|l|l|l|l|l|}
\hline Interval Nilai & Kategori & Tes Diagnostik & Siklus I & Siklus II \\
\hline $90-100$ & Sangat Tinggi & 0 & 2 & 13 \\
\hline $80-89$ & Tinggi & 1 & 7 & 11 \\
\hline $70-79$ & Sedang & 3 & 15 & 9 \\
\hline $60-69$ & Rendah & 15 & 10 & 2 \\
\hline $0-59$ & Sangat Rendah & 16 & 1 & 0 \\
\hline Jumlah & 35 & 35 & 35 \\
\hline Rata-rata kelas & 50,14 & 70,79 & 84,36 \\
\hline Persentase ketuntasan klasikal & $11,43 \%$ & $65,71 \%$ & $94,29 \%$ \\
\hline Persentase yang tidak tuntas & $88,57 \%$ & $34,29 \%$ & $5,71 \%$ \\
\hline
\end{tabular}

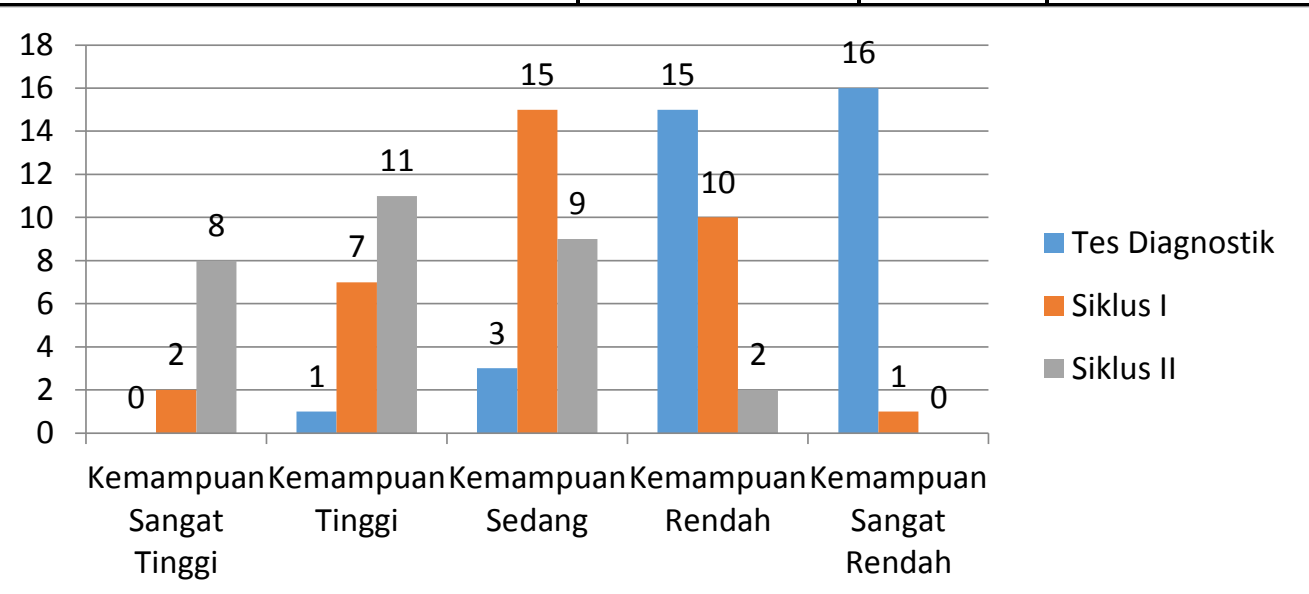

Gambar 2. Tingkat Kemampuan Pemecahan Masalah Siswa Pada Setiap Tindakan

1. Deskripsi Hasil Tes Kemampuan Pemecahan Masalah I

Adapun pelaksanaan tes siklus I setelah pembelajaran dengan menggunakan Model Pembelajaran Problem Based Learning yang telah dilaksanakan pada tanggal 21 November 2017 dengan 35 siswa. Berdasarkan hasil jawaban siswa dari tes kemampuan pemecahan masalah siswa sebagai berikut:
1. Kemampuan siswa dalam memahami masalah, dalam hal ini tingkat kemampuan siswa dalam menulis apa yang diketahui dan apa yang ditanya dala soal (kategori I) pada lampiran 20, terdapat 13 siswa dari 35 siswa atau $37,14 \%$ yang memiliki kemampuan sangat tinggi, 4 siswa dari 35 siswa atau $11,43 \%$ yang memiliki kemampuan tinggi, 14 siswa dari 35 siswa atau $40 \%$ yang memiliki kemampuan sedang, 4 siswa dari 35 siswa atau $11,43 \%$

Marojahan Panjaitan, Sri R Rajagukguk. Upaya Meningkatkan Kemampuan Pemecahan Masalah Matematika Siswa dengan Menggunakan Model Pembelajaran Problem Based Learning di Kelas X SMA. Jurnal Inspiratif, Vol. 3 No. 2 Agustus 2017 
yang memiliki kemampuan rendah. Rata-rata skor kemampuan siswa dalam memahami masalah pada tes kemapuan pemecahan masalah siklus I adalah 6,43 dengan persentasi $80 \%$ hasil lengkapnya dapat dilihat tabel berikut :

Tabel 2. Tingkat Kemampuan siswa Memahami Masalah Pada Tes Kemampuan Pemecahan Masalah I

\begin{tabular}{|c|c|c|c|c|}
\hline Nilai & $\begin{array}{l}\text { Tingkat } \\
\text { Kemampuan }\end{array}$ & $\begin{array}{l}\text { Banyak } \\
\text { Siswa }\end{array}$ & $\begin{array}{l}\text { Persentasi } \\
\text { Jumlah Siswa }\end{array}$ & $\begin{array}{l}\text { Rata-rata } \\
\text { Kemampuan } \\
\text { Siswa }\end{array}$ \\
\hline $90-100$ & Sangat tinggi & 13 orang & $37,14 \%$ & \multirow{6}{*}{$\begin{array}{l}6,43 \\
(80 \%) \\
\text { Sedang }\end{array}$} \\
\hline $80-89$ & Tinggi & 4 orang & $11,43 \%$ & \\
\hline $70-79$ & Sedang & 14 orang & $41,17 \%$ & \\
\hline $50-69$ & Rendah & 4 orang & $11,76 \%$ & \\
\hline $0-49$ & Sangat rendah & 0 orang & $0 \%$ & \\
\hline \multicolumn{2}{|l|}{ Jumlah } & 35 orang & $100 \%$ & \\
\hline
\end{tabular}

2. Kemampuan siswa dalam merencanakan pemecahan masalah (kategori II) pada lampiran 20, terdapat 5 siswa dari 35 siswa atau $14,29 \%$ yang memiliki kemampuan sangat tinggi, terdapat 11 siswa dari 35 siswa atau $31,43 \%$ yang memiliki kemampuan tinggi, 12 siswa dari 35 siswa atau $34,29 \%$ yang memiliki kemampuan sedang, terdapat 1 siswa dari 35 siswa atau 2,86\% yang memiliki kemampuan rendah, dan terdapat 6 siswa dari 35 siswa atau $17,14 \%$ yang memiliki kemampuan sangat rendah. Ratarata skor kemampuan siswa dalam merencanakan pemecahan masalah pada tes kemampuan pemecahan masalah siklus I adalah 8,77 dengan persentase $\quad 73,10 \%$ hasil selengkapnya dapat dilihat dari tabel berikut:

Tabel 3. Tingkat Kemampuan Siswa Merencanakan Pemecahan Masalah Pada Tes Kemampuan Pemecahan Masalah I

\begin{tabular}{|c|c|c|c|c|}
\hline Nilai & $\begin{array}{l}\text { Tingkat } \\
\text { Kemampuan }\end{array}$ & $\begin{array}{l}\text { Banyak } \\
\text { Siswa }\end{array}$ & $\begin{array}{l}\text { Persentasi } \\
\text { Jumlah Siswa }\end{array}$ & $\begin{array}{l}\text { Rata-rata } \\
\text { Kemampuan } \\
\text { Siswa }\end{array}$ \\
\hline $90-100$ & Sangat tinggi & 5 orang & $14,29 \%$ & \multirow{6}{*}{$\begin{array}{l}8,77 \\
(73,10 \%) \\
\text { Sedang }\end{array}$} \\
\hline $80-89$ & Tinggi & 11 orang & $31,43 \%$ & \\
\hline $70-79$ & Sedang & 12 orang & $34,29 \%$ & \\
\hline $50-69$ & Rendah & 1 orang & $2,86 \%$ & \\
\hline $0-49$ & Sangat rendah & 6 orang & $17,14 \%$ & \\
\hline \multicolumn{2}{|l|}{ Jumlah } & 35 orang & $100 \%$ & \\
\hline
\end{tabular}

3. Kemampuan siswa dalam terdapat 5 siswa dari 35 siswa atau melaksanakan pemecahan masalah (kategori III) pada lampiran 20, $14,29 \%$ yang memiliki kemampuan sangat tinggi, terdapat 11 siswa dari

Marojahan Panjaitan, Sri R Rajagukguk. Upaya Meningkatkan Kemampuan Pemecahan Masalah Matematika Siswa dengan Menggunakan Model Pembelajaran Problem Based Learning di Kelas X SMA. Jurnal Inspiratif, Vol. 3 No. 2 Agustus 2017 
35 siswa atau $31,43 \%$ yang memiliki kemampuan tinggi, terdapat 4 siswa dari 35 siswa atau $11.43 \%$ yang memiliki kemampuan sedang, terdapat 13 siswa dari 35 siswa atau $37,14 \%$ yang memiliki kemampuan rendah, dan terdapat 2 siswa dari 35 siswa atau $2,71 \%$ yang memiliki kemampuan sangat rendah. Rata-rata skor kemampuan siswa dalam melaksanakan pemecahan masalah pada tes kemampuan pemecahan masalah siklus I adalah 8,86 dengan persentase $\quad 73,81 \%$ hasil selengkapnya dapat dilihat dari tabel berikut:

Tabel 4. Tingkat Kemampuan Siswa Melaksanakan Pemecahan Masalah Pada Tes Kemampuan Pemecahan Masalah I

\begin{tabular}{|c|c|c|c|c|}
\hline Nilai & $\begin{array}{l}\text { Tingkat } \\
\text { Kemampuan }\end{array}$ & $\begin{array}{l}\text { Banyak } \\
\text { Siswa }\end{array}$ & $\begin{array}{l}\text { Persentasi } \\
\text { Jumlah Siswa }\end{array}$ & $\begin{array}{l}\text { Rata-rata } \\
\text { Kemampuan Siswa }\end{array}$ \\
\hline $90-100$ & Sangat tinggi & 5 orang & $14,29 \%$ & \multirow{6}{*}{$\begin{array}{l}8,86 \\
(73,81 \%) \\
\text { Sedang }\end{array}$} \\
\hline $80-89$ & Tinggi & 11 orang & $31,43 \%$ & \\
\hline $70-79$ & Sedang & 4 orang & $11,43 \%$ & \\
\hline $50-69$ & Rendah & 13 orang & $37,14 \%$ & \\
\hline $0-49$ & Sangat rendah & 2 orang & $2,71 \%$ & \\
\hline \multicolumn{2}{|l|}{ Jumlah } & 35 orang & $100 \%$ & \\
\hline
\end{tabular}

4. Kemampuan siswa dalam memeriksa kembali pemecahan masalah (kategori IV) pada lampiran 20, terdapat 1 siswa dari 35 siswa atau $2,86 \%$ yang memiliki kemampuan sangat tinggi, 1 siswa dari 35 siswa atau $2,86 \%$ yang memiliki kemampuan tinggi, terdapat 7 siswa dari 35 siswa atau $20 \%$ yang memiliki kemampuan sedang, terdapat 6 siswa dari 35 kemampuan rendah, dan terdapat 20 siswa dari 35 siswa atau $57,14 \%$ yang memiliki kemampuan sangat rendah. Rata-rata skor kemampuan siswa dalam memeriksa kembali pemecahan masalah pada tes kemampuan pemecahan masalah siklus I adalah 4,69 dengan persentase $\quad 58,57 \% \quad$ hasil selengkapnya dapat dilihat dari tabel berikut:

siswa atau $17,14 \%$ yang memiliki

Tabel 5. Tingkat Kemampuan Siswa Memeriksa Kembali Pemecahan Masalah Pada Tes Kemampuan Pemecahan Masalah I

\begin{tabular}{|c|c|c|c|c|}
\hline Nilai & $\begin{array}{l}\text { Tingkat } \\
\text { Kemampuan }\end{array}$ & $\begin{array}{l}\text { Banyak } \\
\text { Siswa }\end{array}$ & $\begin{array}{l}\text { Persentasi } \\
\text { Jumlah Siswa }\end{array}$ & $\begin{array}{l}\text { Rata-rata } \\
\text { Kemampuan } \\
\text { Siswa }\end{array}$ \\
\hline $90-100$ & Sangat tinggi & 1 orang & $2,86 \%$ & \multirow{5}{*}{$\begin{array}{l}4,69 \\
(58,57 \%) \\
\text { Rendah }\end{array}$} \\
\hline $80-89$ & Tinggi & 1 orang & $2,86 \%$ & \\
\hline $70-79$ & Sedang & 7 orang & $20 \%$ & \\
\hline $50-69$ & Rendah & 6 orang & $17,14 \%$ & \\
\hline $0-49$ & Sangat rendah & 20 orang & $57,14 \%$ & \\
\hline
\end{tabular}

Dari data di atas dapat dilihat berdasarkan diagram sebagai berikut: 


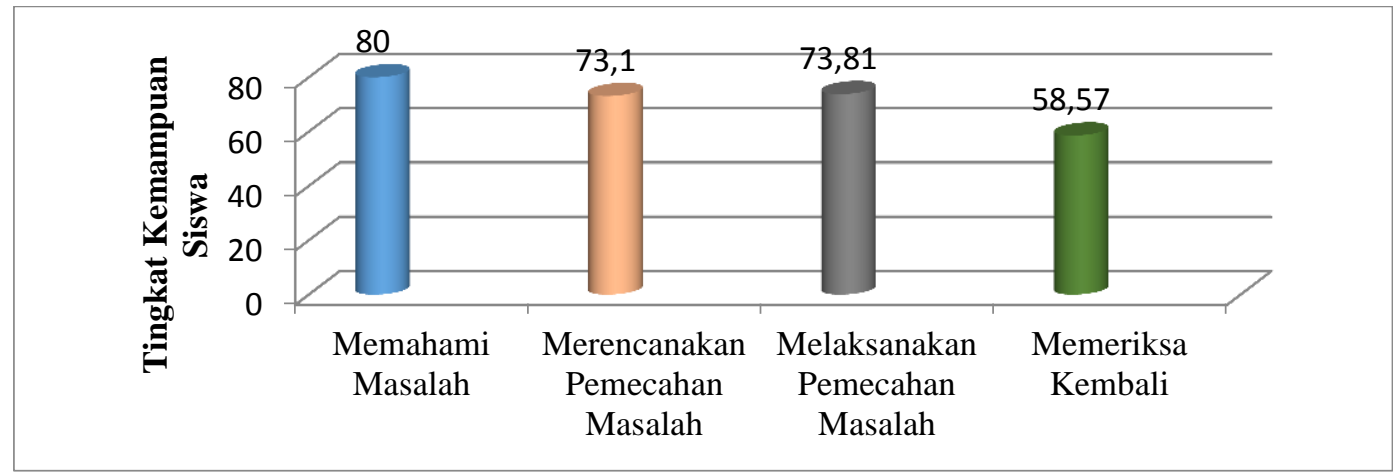

\section{Gambar 3. Tingkat Kemampuan Pemecahan Masalah Siswa Pada Tes Kemampuan Pemecahan Masalah I}

Berdasarkan tes kemampuan pemecahan masalah I yang telah diberikan kepada 35 siswa, berikut rincian indikator pencapaian kemampuan pemecahan masalah, terdapat 2 siswa dari 35 siswa atau $5,71 \%$ mempunyai kemampuan pemecahan masalah yang sangat tinggi, terdapat 7 siswa dari 35 siswa atau $20 \%$ mempunyai kemampuan pemecahan masalah tinggi, terdapat 15 siswa dari 35 siswa atau $42,86 \%$ mempunyai kemampuan pemecahan masalah sedang, terdapat 10 siswa dari 35 siswa atau $28,57 \%$ mempunyai kemampuan pemecahan masalah rendah, dan terdapat 1 siswa dari 35 siswa atau 2,86\% mempunyai kemampuan pemecahan masalah sangat rendah. Rata-rata skor kemampuan siswa dalam menyelesaikan tes kemampuan pemecahan masalah siklus I adalah 28,54 dengan persentase $70,79 \%$ hasil selengkapnya dapat dilihat dari tabel berikut:

\section{Tabel 6. Deskripsi Tingkat Kemampuan Pemecahan Masalah Siswa} Pada Tes Kemampuan Pemecahan I

\begin{tabular}{|c|c|c|c|c|}
\hline Nilai & $\begin{array}{l}\text { Tingkat } \\
\text { Kemampuan }\end{array}$ & $\begin{array}{l}\text { Banyak } \\
\text { Siswa }\end{array}$ & $\begin{array}{l}\text { Persentasi } \\
\text { Jumlah Siswa }\end{array}$ & $\begin{array}{l}\text { Rata-rata } \\
\text { Kemampuan } \\
\text { Siswa }\end{array}$ \\
\hline $90-100$ & Sangat tinggi & 2 orang & $5,71 \%$ & \multirow{5}{*}{$\begin{array}{l}28,54 \\
(70,79 \%) \\
\text { Sedang }\end{array}$} \\
\hline $80-89$ & Tinggi & 7 orang & $20 \%$ & \\
\hline $70-79$ & Sedang & 15 orang & $42,86 \%$ & \\
\hline $50-69$ & Rendah & 10 orang & $28,57 \%$ & \\
\hline $0-49$ & Sangat rendah & 1 orang & $2,86 \%$ & \\
\hline Jumlah & & 35 orang & $100 \%$ & \\
\hline
\end{tabular}

Secara keseluruhan, tingkat kemampuan siswa dalam memecahkan masalah pada tes kemampuan pemecahan masalah I adalah 70,79\% dengan nilai rata-rata 28,54. Jumlah siswa yang telah mencapai ketuntasan sebanyak 23 siswa dari 35 siswa atau $65,71 \%$, sedangkan jumlah siswa yang belum mencapai ketuntasan sebanyak 12 siswa dari 34 siswa atau 34,29\%. Hal ini dapat dilihat dari diagram sebagai berikut: 


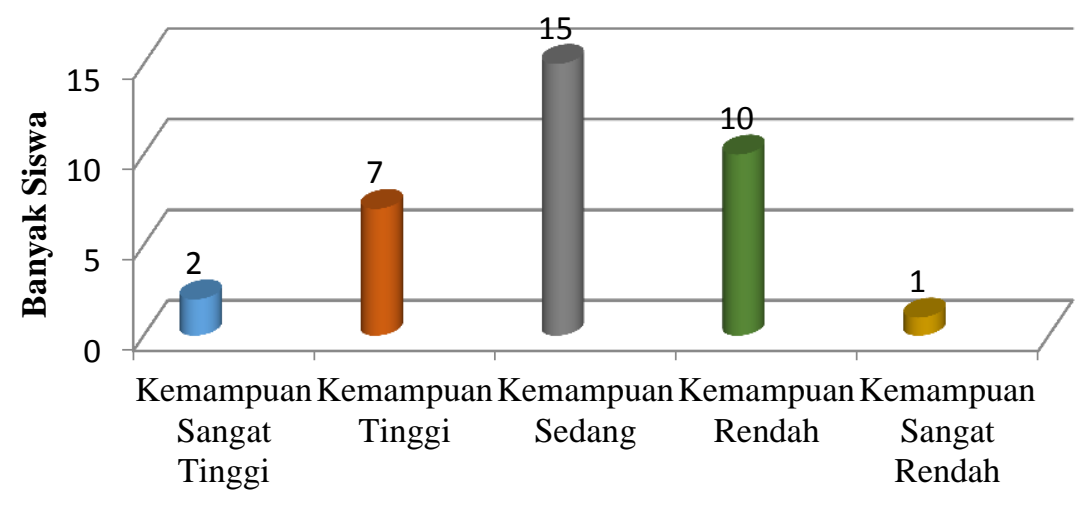

\section{Gambar 4. Deskripsi Tingkat Keampuan Pemecahan Masalah Siswa Pada Tes Kemampuan Pemecahan Masalah I}

\section{Deskripsi Hasil Tes Kemampuan Pemecahan Masalah II}

Kriteria penilaian pada tes pemecahan masalah II ini, sama dengan kriteria penilaian pemecahan masalah pada siklus I, yaitu penilaian pada setiap langkah pemecahan masalah (1) kemampuan memahami masalah, (2) kemampuan merencanakan pemecahan masalah, (3) kemampuan melaksanakan pemecahan masalah sesuai rencana, dan (4) kemampuan memeriksa kembali pemecahan masalah. Berdasarkan data pada tes kemampuan pemecahan masalah II, dapat dilihat kemampuan siswa dalam menyelesaikan sebagai berikut:
1. Kemampuan siswa dalam memahami masalah, dalam hal ini tingkat kemampuan siswa dalam menulis apa yang diketahui dan apa yang ditanya dala soal (kategori I) pada lampiran 26, terdapat 19 siswa dari 35 siswa atau $54,29 \%$ yang memiliki kemampuan sangat tinggi, 7 siswa dari 35 siswa atau $20 \%$ yang memiliki kemampuan tinggi, dan 9 siswa dari 35 siswa atau $25,71 \%$ yang memiliki kemampuan sedang. Rata-rata skor kemampuan siswa dalam memahami masalah pada tes kemapuan pemecahan masalah siklus I adalah 7,29 dengan persentasi 91,07\% hasil lengkapnya dapat dilihat tabel berikut:

Tabel 7. Tingkat Kemampuan siswa Memahami Masalah Pada Tes Kemampuan Pemecahan Masalah II

\begin{tabular}{|c|c|c|c|c|}
\hline Nilai & $\begin{array}{l}\text { Tingkat } \\
\text { Kemampuan }\end{array}$ & $\begin{array}{l}\text { Banyak } \\
\text { Siswa }\end{array}$ & $\begin{array}{l}\text { Persentasi } \\
\text { Jumlah Siswa }\end{array}$ & $\begin{array}{l}\text { Rata-rata } \\
\text { Kemampuan } \\
\text { Siswa }\end{array}$ \\
\hline $90-100$ & Sangat tinggi & 19 orang & $54,29 \%$ & \multirow{6}{*}{$\begin{array}{l}7,29 \\
(91,07 \%) \\
\text { Sangat Tinggi }\end{array}$} \\
\hline $80-89$ & Tinggi & 7 orang & $20 \%$ & \\
\hline $70-79$ & Sedang & 9 orang & $25,71 \%$ & \\
\hline $50-69$ & Rendah & 0 orang & $0 \%$ & \\
\hline $0-49$ & Sangat rendah & 0 orang & $0 \%$ & \\
\hline Jumlah & & 35 orang & $100 \%$ & \\
\hline
\end{tabular}

Marojahan Panjaitan, Sri R Rajagukguk. Upaya Meningkatkan Kemampuan Pemecahan Masalah Matematika Siswa dengan Menggunakan Model Pembelajaran Problem Based Learning di Kelas X SMA. Jurnal Inspiratif, Vol. 3 No. 2 Agustus 2017 
2. Kemampuan siswa dalam merencanakan pemecahan masalah (kategori II) pada lampiran 26, terdapat 6 siswa dari 35 siswa atau $17,14 \%$ yang memiliki kemampuan sangat tinggi, 8 siswa dari 35 siswa atau $20,58 \%$ yang memiliki kemampuan tinggi, dan terdapat 21 siswa dari 35 siswa atau $61,76 \%$

memiliki kemampuan sedang. Rata-rata skor kemampuan siswa dalam memahami masalah pada tes kemampuan pemecahan masalah II adalah 9,34 dengan persentase mencapai 77,95\%. Hasil selengkapnya dapat dilihat pada tabel sebagai berikut:

Tabel 8. Tingkat Kemampuan siswa Merencanakan Masalah Pada Tes Kemampuan Pemecahan Masalah II

\begin{tabular}{|l|l|l|l|l|}
\hline Nilai & $\begin{array}{l}\text { Tingkat } \\
\text { Kemampuan }\end{array}$ & $\begin{array}{l}\text { Banyak } \\
\text { Siswa }\end{array}$ & $\begin{array}{l}\text { Persentasi } \\
\text { Jumlah Siswa }\end{array}$ & $\begin{array}{l}\text { Rata-rata } \\
\text { Kemampuan } \\
\text { Siswa }\end{array}$ \\
\hline $90-100$ & Sangat tinggi & 6 orang & $17,14 \%$ & \\
\hline $80-89$ & Tinggi & 8 orang & $22,86 \%$ & \multirow{2}{*}{$\begin{array}{l}(77,26 \\
\text { Sedang }\end{array}$} \\
\hline $70-79$ & Sedang & 21 orang & $60 \%$ & \\
\hline $50-69$ & Rendah & 0 orang & $0 \%$ & \\
\hline $0-49$ & Sangat rendah & 0 orang & $0 \%$ & $100 \%$ \\
\cline { 1 - 2 } Jumlah & & 35 orang & & \\
\cline { 1 - 2 } & & & &
\end{tabular}

3. Kemampuan siswa dalam melaksanakan pemecahan masalah (kategori III) pada lampiran 26, terdapat 18 siswa dari 35 siswa atau $51,43 \%$ yang memiliki kemampuan sangat tinggi, 13 siswa dari 35 siswa atau $37,14 \%$ yang memiliki kemampuan tinggi, dan 4 siswa dari 35 siswa atau $11,43 \%$ yang memiliki kemampuan sedang. Ratarata skor kemampuan siswa dalam melaksanakan masalah pada tes kemampuan pemecahan masalah siklus I adalah 10,74 dengan persentasi $\quad 89,52 \%$ hasil lengkapnya dapat dilihat tabel berikut:

Tabel 9. Tingkat Kemampuan Siswa Melaksanakan Pemecahan Masalah Pada Tes Kemampuan Pemecahan Masalah II

\begin{tabular}{|c|c|c|c|c|}
\hline Nilai & $\begin{array}{l}\text { Tingkat } \\
\text { Kemampuan }\end{array}$ & $\begin{array}{l}\text { Banyak } \\
\text { Siswa }\end{array}$ & $\begin{array}{l}\text { Persentasi } \\
\text { Jumlah Siswa }\end{array}$ & $\begin{array}{l}\text { Rata-rata } \\
\text { Kemampuan } \\
\text { Siswa }\end{array}$ \\
\hline $90-100$ & Sangat tinggi & 18 orang & $51,43 \%$ & \multirow{6}{*}{$\begin{array}{l}10,74 \\
(89,52 \%) \\
\text { Sangat Tinggi }\end{array}$} \\
\hline $80-89$ & Tinggi & 13 orang & $37,14 \%$ & \\
\hline $70-79$ & Sedang & 4 orang & $11,43 \%$ & \\
\hline $50-69$ & Rendah & 0 orang & $0 \%$ & \\
\hline $0-49$ & Sangat rendah & 0 orang & $0 \%$ & \\
\hline \multicolumn{2}{|l|}{ Jumlah } & 35 orang & $100 \%$ & \\
\hline
\end{tabular}

Marojahan Panjaitan, Sri R Rajagukguk. Upaya Meningkatkan Kemampuan Pemecahan Masalah Matematika Siswa dengan Menggunakan Model Pembelajaran Problem Based Learning di Kelas X SMA. Jurnal Inspiratif, Vol. 3 No. 2 Agustus 2017 
4. Kemampuan siswa dalam memeriksa kembali pemecahan masalah (kategori IV) pada lampiran 26, terdapat 11 siswa dari 34 siswa atau $32,35 \%$ yang memiliki kemampuan sangat tinggi, 9 siswa dari 34 siswa atau 26,47\% yang memiliki kemampuan tinggi, 9 siswa dari 34 siswa atau 26,47\% yang memiliki kemampuan sedang,

dan 5 siswa dari 34 siswa atau $14,70 \%$ yang memiliki kemampuan rendah. Rata-rata skor kemampuan siswa dalam memeriksa kembali pada tes kemampuan pemecahan masalah II adalah 6,85 dengan persentase mencapai $85,64 \%$. Hasil selengkapnya dapat dilihat pada tabel sebagai berikut:

Tabel 10. Tingkat Kemampuan Siswa Memeriksa Kembali Pemecahan Masalah Pada Tes Kemampuan Pemecahan Masalah II

\begin{tabular}{|c|c|c|c|c|}
\hline Nilai & $\begin{array}{l}\text { Tingkat } \\
\text { Kemampuan }\end{array}$ & $\begin{array}{l}\text { Banyak } \\
\text { Siswa }\end{array}$ & $\begin{array}{l}\text { Persentasi } \\
\text { Jumlah Siswa }\end{array}$ & $\begin{array}{l}\text { Rata-rata } \\
\text { Kemampuan } \\
\text { Siswa }\end{array}$ \\
\hline $90-100$ & Sangat tinggi & 12 orang & $34,29 \%$ & \multirow{6}{*}{$\begin{array}{l}6,80 \\
(85 \%) \\
\text { Tinggi }\end{array}$} \\
\hline $80-89$ & Tinggi & 9 orang & $25,71 \%$ & \\
\hline $70-79$ & Sedang & 9 orang & $25,71 \%$ & \\
\hline $50-69$ & Rendah & 5 orang & $14,29 \%$ & \\
\hline $0-49$ & Sangat rendah & 0 orang & $0 \%$ & \\
\hline Jumlah & & 35 orang & $100 \%$ & \\
\hline
\end{tabular}

Dari data di atas dapat dilihat berdasarkan diagram sebagai berikut:

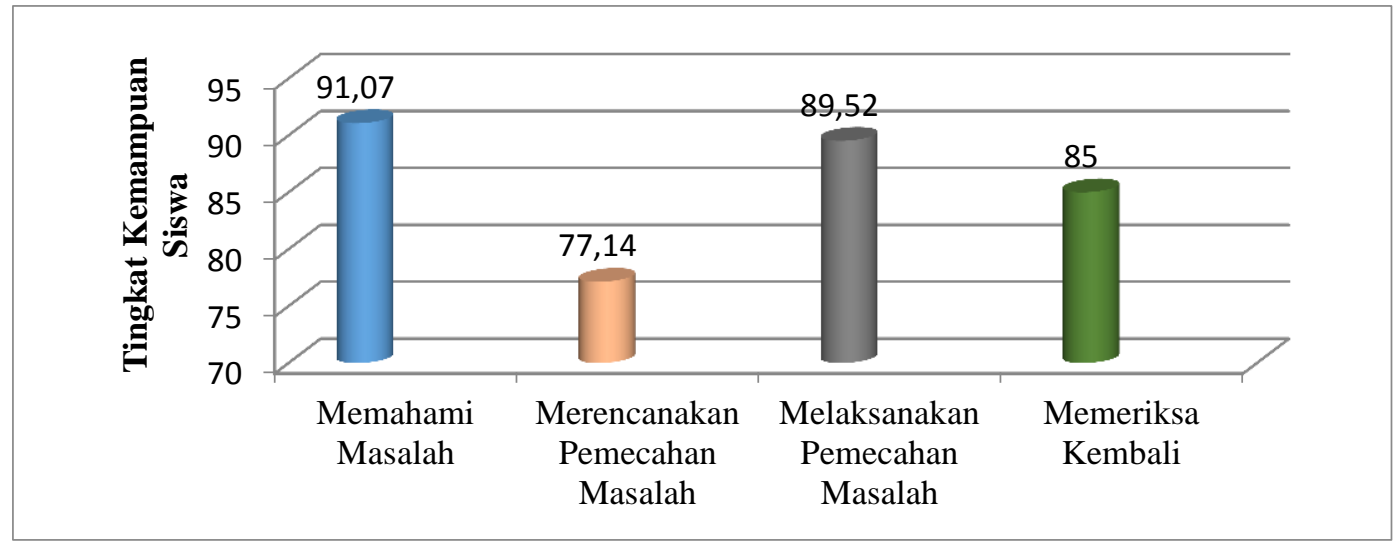

\section{Gambar 5. Tingkat Kemampuan Pemecahan Masalah Siswa Pada Tes Kemampuan Pemecahan Masalah II}

Berdasarkan tes kemampuan pemecahan masalah II yang telah diberikan kepada 34 siswa, berikut rincian indikator pencapaian kemampuan pemecahan masalah siswa, terdapat 13 siswa dari 34 siswa atau $38,23 \%$ mempunyai kemampuan pemecahan masalah sangat tinggi, 10 siswa dari 34 siswa atau
$29,41 \%$ mempunyai kemampuan pemecahan masalah tinggi, dan 9 siswa dari 34 siswa atau 26,47\% mempunyai kemampuan pemecahan masalah sedang, dan 2 siswa dari 34 siswa atau $5,88 \%$ mempunyai kemampuan pemecahan masalah rendah. 


\section{Pembahasan}

Berdasarkan hasil penelitian yang diperoleh bahwa model pembelajaran berbasis masalah dapat meningkatkan kemampuan pemecahan masalah matematika pada siswa kelas X SMA Negeri 14 Medan pada materi system persamaan linear dua variabel. Peningkatan kemampuan pemecahan masalah matematika siswa terlihat dari peningkatan nilai rata-rata, peningkatan penguasaan (kemampuan pemecahan masalah matematika) siswa persentase ketuntasan belajar individu dan ketuntasan belajar klasikal. Dengan demikian model pembelajaran berbasis masalah merupakan salah satu upaya yang dapat dilakukan untuk meningkatkan kemampuan pemecahan masalah matematika siswa.

Ada beberapa teori belajar yang mendukung hasil tersebut, yaitu teori belajar Konstruktivisme. Menurut pandangan konstruktivisme, belajar merupakan suatu proses pembentukan pengetahuan. Pembentukan ini harus dilakukan oleh siswa. Ini berarti sesuai dengan karakteristik dari Problem Based Learning (PBL) bahwa pembelajaran itu harus berpusat pada siswa. Teori ini menjelaskan peranan utama dalam kegiatan belajar adalah aktivitas siswa dalam mengkonstruksi pengetahuannya sendiri, melalui bahan, media, peralatan, lingkungan, dan fasilitas lainnya yang disediakan untuk membantu pembentukan tersebut. Peranan guru pada pendekatan ini lebih sebagai mediator dan fasilitator bagi siswa. Hal senada yang datang dari teori belajar yang mengemukakan bahwa pengetahuan yang dimiliki seseorang merupakan hasil konstruksi(bentukan) orang itu sendiri. Selanjutnya menurut teori belajar kognitivistik, pengetahuan dibangun dalam diri seseorang melalui proses interaksi yang berkesinambungan dengan lingkungan. Menurut psikologi kognitif, belajar diapndang sebagai suatu usaha untuk mengerti sesuatu. Usaha itu dilakukan oleh siswa. Keaktifan itu dapat berupa mencari pengalaman, mencari informasi, memecahkan masalah, mencermati lingkungan, mempraktikkan sesuatu untuk mencapai suatu tujuan tertentu (Surya, 2017). Dengan melihat hasil pengamatan dan hasil belajar siswa yang diperoleh dalam siklus II, maka hipotesis dapat dicapai, sehingga tidaklah perlu dilakukan siklus selanjutnya.

Hasil penelitian ini juga didukung oleh penelitian yang sebelumnya yang dilakukan oleh Anting (2015) di kelas VIII SMP Negeri 1 Badiri, menyatakan bahwa terdapat peningkatan pemecahan masalah. Nilai rata-rata kemampuan pemecahan masalah yang berjumlah 42 siswa pada tes diagnostik adalah $27,74 \%$. Setelah dilakukannya tes pada siklus I, nilai ratarata kemampuan pemecahan masalah meningkatkan menjadi 63,03 dengan tingkat ketuntasan klasikal 52,94\% dan setelah dilakukan siklus II, diperoleh rata-rata tes kemampuan pemecahan masalah siswa menjadi 32,45 dengan ketuntasan klasikal 85,29\%.

Data yang diperoleh di atas menunjukkan bahwa kegiatan belajar mengajar dan penyampaian materi pelajaran pada pokok bahasan system persamaan linear dua variabel dapat diupayakan berhasil dengan menggunakan model pembelajaran Problem Based Learning dan dapat ditingkatkan. Dengan demikian pembelajaran dengan menerapkan model pembelajaran Problem Based Learning

Marojahan Panjaitan, Sri R Rajagukguk. Upaya Meningkatkan Kemampuan Pemecahan Masalah Matematika Siswa dengan Menggunakan Model Pembelajaran Problem Based Learning di Kelas X SMA. Jurnal Inspiratif, Vol. 3 No. 2 Agustus 2017 
mempunyai peranan penting sebagai salah satu upaya untuk meningkatkan

\section{Kesimpulan}

Berdasarkan hasil analisis data dan pembahasan bab IV, kesimpulan yang diperoleh pada penelitian adalah penerapan model pembelajaran Problem Based Learning dapat meningkatkan kemampuan pemecahan masalah matematika siswa kelas X MIPA 1 SMA Negeri 14 Medan dengan membagi setiap kelompok terdiri dari 5-6 orang, memberikan masalah - masalah yang berkaitan dengan dunia nyata yang lebih bervariasi, guru memberikan reward kepada kelompok yang terbaik, selalu mengadakan evaluasi dan refleksi pada akhir pembelajaran yang telah dilakukan, sehingga kesulitan yang mempengaruhi keberhasilan

\section{Saran}

Adapun saran yang dapat diambil dari hasil penelitian ini, yaitu:

1. Kepada guru khususnya guru matematika disarankan memperhatikan kemampuan siswa dalam memecahkan masalah dan melibatkan siswa dalam proses pembelajaran yang aktif, dan menggunakan model pembelajaran Problem Based Learning sebagai salah satu alternatif untuk

\section{DAFTAR PUSTAKA} Pendidikan Bagi Anak Berkesulitan Belajar, Rineka Cipta, Jakarta.

BSNP, (2006), Permendiknas No. 22 Tahun 2006, Depdiknas : Jakarta.
Abdurrahman, Mulyono, (2012),

kemampuan pemecahan masalah matematika siswa.

pembelajaran baik yang dialami siswa maupun guru pada pembelajaran ini dapat diatasi dengan segera mungkin. Hal ini dapat dilihat dari peningkatan kemampuan pemecahan masalah siswa sebesar $28,58 \%$ dari $65,71 \%$ pada siklus I meningkat menjadi $94,29 \%$ pada siklus II. Selain itu, pada siklus I jumlah siswa yang mencapai peningkatan kemampuan pemecahan masalah sebanyak 23 siswa dari 35 siswa pada siklus I meningkat menjadi 33 siswa pada siklus II. Nilai rata-rata kelas 70,79 pada siklus I dan meningkat menjadi 84,36 pada siklus II sehingga diperolah peningkatan nilai rata-rata kemampuan pemecahan masalah siswa sebesar 13,57.

$$
\begin{array}{ll}
\text { meningkatkan } & \text { kemampuan } \\
\text { pemecahan masalah matematika } \\
\text { siswa.. }
\end{array}
$$

2. Kepada peneliti lanjutan agar hasil dan perangkat penelitian ini dapat dijadikan pertimbangan untuk menerapkan model pembelajaran Problem Based Learning pada materi sistem persamaan linier dua variabel ataupun materi lain yang dapat dikembangkan untuk penelitian selanjutnya.

Cockroft, W.H., (1982), Mathematics Count, Commercial Colour Press, London.

Hadijah, S., dkk, (2016), Pengaruh Pembelajaran Kooperatif Tipe Jigsaw Terhadap Kemampuan Pemahaman Konsep dan

Marojahan Panjaitan, Sri R Rajagukguk. Upaya Meningkatkan Kemampuan Pemecahan Masalah Matematika Siswa dengan Menggunakan Model Pembelajaran Problem Based Learning di Kelas X SMA. Jurnal Inspiratif, Vol. 3 No. 2 Agustus 2017 
Komunikasi Matematik Siswa, Jurnal Tabularasa PPS UNIMED, 13 : 285 - 298

Hasratuddin., (2015), Mengapa Harus Belajar Matematika, Malang: Perdana Publishing, Jakarta.

Hudojo., (2005), Pengembangan Kurikulum dan Pembelajaran Matematika. Penerbit UM Press. Isjoni,H., (2009), Pembelajaran Kooperatif, Pustaka Belajar, Yogyakarta.

Lubis, D.S., dkk., (2015), Peningkatan Kemampuan Pemecahan Masalah Matematik dan Kemandirian Belajar Siswa SMP melalui Model Pembelajaran Berbasis Masalah, Jurnal Paradikma, Vol.8, Nomor3

Minarni, A., (2013), Pengaruh Pembelajaran Berbasis Masalah Terhadap Kemampuan Pemahaman Matematis Siswa SMP Negeri Di Kota Bandung, Jurnal Paradikma, Vol.6, Nomor 2

Minarni, A., (2012), Pengaruh Pembelajaran Berbasis Masalah Terhadap Kemampuan Pemahaman Matematis. Prosiding Seminar Nasional FMIPA UNIMED, ISBN:978979-16353-8-7. (Diakses 17 September 2017).

Napitupulu dan Mansyur. (2011). Kemampuan Pemecahan Masalah Matematis Siswa. Generasi Kampus, 4 : 139-148.

Nurdalilah, dkk. 2013. Perbedaan Kemampuan Penalaran Matematika dan Pemecahan Masalah pada Pembelajaran Berbasis Masalah dan Pembelajaran Konvensional di SMA negeri 1 Kualuh Selatan,
Jurnal Pendidikan Matematika PARADIKMA, 6 : 109-119

Padmavathy, R.D, dan K, Maaresh.Effectiveness of Problem Based Learning In Mathematics. International Multidisciplinary e-Journal. ISSN 2277-4262, 2013. Diambil dari http://shreeprakashan.com/Doc uments/2013128181315606.6. \%20Padma\%20Sasi.pdf(diakse s pada tanggal 20 Agustus 2017).

PISA 2012. 2013. Result in Focus, What 15-Year-Olds Known and Why They can do with what they know. OECD, Programme for International Student Assesment.

Polya, G., (1973), How To Solve It, A New Aspect of Mathematical Method, Princeton University, Princeton.

Surya, E dan Novalina, R. (2017). Pengaruh Problem Based Learning (PBL) Terhadap Kemampuan Pemecahan Masalah Matematika Siswa SMP. Jurnal Kepustakaan. https://www.researchgate.net/pu blication/320322613

Trianto, (2011), Mendesain Model Pembelajaran InovatifProgresif, Kencana Prenada Media grup, Jakarta.

Wicaksana,A. $2014 \quad$.Komparasi Kemampuan Pemecahan Masalah Antara Pembelajaran MEAs Dan Arias Materi Kubus dan Balok Kelas-VIII . Diambil dari http://lib.unnes.ac.id/21271/1/4 101410053-S.pdf (15 Agustus 2017). 